and orchestral, and for various types of exhibitions. The fire affected the Research Laboratories of Baird Television, Ltd., situated at the Palace, but the part of the building leased by the Baird Company for the production of receiver sets and their testing fortunately was sufficiently remote from the main building not to be damaged in any way. While, therefore, a great amount of research apparatus was destroyed, the delivery of Baird receiving sets will not be seriously affected. Immediate measures are being taken to find alternative accommodation for the Baird Company's large number of research workers and for the re-equipment of the laboratories, and it is not considered that the research programme of the Company will be seriously prejudiced. The fire at the Crystal Palace does not affect the B.B.C. television programmes being broadcast from the Alexandra Palace by the Baird system and by the Marconi E.M.I. system.

\section{Television in the London Area}

THE issue of Television and Short Wave World of December makes some critical comments on the programmes that have been transmitted from the Alexandra Palace. Complaints are made that intervals, sometimes totalling more than fifteen minutes, occur in a programme of an hour. These intervals are usually filled up by gramophone records, but the owner of the set feels that it is extravagant to run about twenty valves together with a cathode ray tube merely to hear these records. It is unfair to be too critical in the early stages of development, but it looks as if more should be spent on the programmes. Television receivers are being advertised for immediate delivery at prices ranging from 85 to 135 guineas, the picture size being about 12 in. by 9 in. Free demonstrations are given by various manufacturers in London. The Science Museum is still giving demonstrations, and the Southern Railway is giving demonstrations at Waterloo Station to railway ticket holders. Carrington House, a large block of flats in Mayfair, has been equipped for 'bulk reception' of television signals and of ordinary broadcast programmes. The building contains seventy-three flats each of which is fitted with plug points for both kinds of services. The residents of any of these flats can purchase a television or a radio set or both with confidence that the programmes will be produced without interference. It is possible that the actual Coronation ceremony in Westminster Abbey may be televized. The two great difficulties are relaying the signals to the Alexandra Palace and the provision of the necessary bright light.

\section{Derbyshire Caves Exhibition}

ON behalf of the Derbyshire Caves Exploration Committee appointed by the British Association, $\mathbf{M r}$. Leslie Armstrong has excavated Pin Hole, a cave in Creswell Crags inhabited in Upper Palæolithic times and exceptionally rich in prehistoric remains. A preliminary report was published in the Transactions of the Hunter Archaeological Society, 4, part 2, with a diagram showing the brick-earth, red above and yellow below, which underlay the present stalagmitic floor, with layers of slabs fallen from the roof marking periods of exceptional cold. The palæolithic cultures represented are Le Moustier and Aurignac, the latter persisting through the glaciation associated elsewhere with La Madeleine; and the fauna shows severe and temperate conditions alternating. There are chipped pebbles of quartzite, and flint implements of excellent workmanship, nearly all with white patina; also slight engravings on bone, a bone blade regarded as a bull-roarer, as well as a cowrie shell and piece of mother-of-pearl. Mr. Armstrong has also excavated Mother Grundy's Parlour in the same valley, and published an account in the Journal of the Royal Anthropological Institute, 55, Jan.-June 1925, with eight pages of careful drawings of the stone implements mostly of Aurignac types, but with a microlithic industry in the uppermost layer, and chipped quartzite at the base. The cave-earth of the Parlour has large stones from the roof incorporated throughout, not at intervals, and shows the same difference in colour as Pin Hole. Engravings of animals on bone in the Aurignac style and the best of the finds from both sites are now exhibited in the Department of British and Mediaeval Antiquities at the British Museum, near the top of the main staircase, and will, by the kindness of Mr. Armstrong, remain there for the rest of the year.

\section{Romano-British Pottery Kiln from Berkshire}

A Romano-Brimish pottery kiln removed intact to the Science Museum, South Kensington, from its original site in Berkshire was exhibited to the public for the first time on December 1. The kiln, now shown with a reproduction of its original surroundings painted by Mr. E. M. Dinkel as a background, is one of two discovered through the introduction of the tractor-drawn plough in the cultivation of a field overlooking the dried-up bed of the River Pang on Woodrows Farm, Compton, near Aldworth, Berks. The deeper ploughing in soil only a few inches deep on chalk turned up a darker earth mixed with potsherds, which on investigation by General W. K. Hardy proved to be due to the presence of two pottery kilns. Of these, one was found to be intact, while the other had been broken up by the ancient potter. The kilns had been constructed by digging an oval hole in the chalk about four feet deep. One half of this was taken up by a rough oven of clay with a front wall of clay and stones, in which was a stoke-hole. A floor of clay, supported by a wall from centre to back, an inch or two below the level of the chalk, served as the stand on which were placed the 'green' pots for firing, heat from the fire passing through holes in the floor. Over the pots had been a dome-shaped cover of clay, which had to be broken at each firing, but of which fragments were found nearby. Pots reconstructed from the numerous sherds collected, as well as coins associated with the find, give a date not later than the beginning of the fourth century A.D. The removal intact of the undamaged kiln entailed not a little skill and in genuity, as with reinforcement it weighed nearly 